\title{
Composite material obtained by powder metallurgy with applications in the automotive industry
}

\author{
Cristina lleana PASCU ${ }^{1, a^{*}}$, Stefan GHEORGHE ${ }^{1, b}$, Claudiu NICOLICESCU ${ }^{1, c}$ and \\ Daniela TARATA ${ }^{1, d}$ \\ ${ }^{1}$ Faculty of Mechanics, University of Craiova, Craiova, Romania \\ a_pascu@yahoo.com, bstgheo@yahoo.com, cnicolicescu_claudiu@yahoo.com, \\ danielatarata@yahoo.com.
}

*i_pascu@yahoo.com

Keywords: Titanium hydride, Powder Metallurgy, Two-Steps Sintering, Multiple-Steps Sintering, Microstructure.

\begin{abstract}
Because of their great properties titanium and titanium alloys have been used in automotive industry, biomedical applications, aerospace industry, computer components, emerging applications, architecture of buildings, etc. In the last decade there has been revived interest in the utilization of the Powder Metallurgy (PM) route as a low-cost way for obtaining components from this alloys. This research presents the experimental results concerning the processing of Ti based alloy by Two-Steps Sintering and Multiple-Steps Sintering, techniques belonging to $\mathrm{PM}$ technology. The initial powder mixture consists in $\mathrm{TiH}_{2}$ powder particles that have been combined with some metallic powders (Al, Mn, Sn, $\mathrm{Zr}$ ) for improving the final mechanic-chemicals and functional properties for using in the automotive industry. As a result it was studied the physical-mechanical properties after sintering, the influence of the sintering temperature and time on the microstructural changes of the composite material based on titanium.
\end{abstract}

\section{Introduction}

Titanium alloys have multiple applications in diverse fields such as industrial and medical fields [1-4]. This is due to their excellent performances such as: low density, good corrosion resistance, non-magnetic properties, high specific strength, high chemical stability, resistant to high temperatures, etc. [5,6]. The basic advantages of titanium alloys in terms of the automotive industry are the high strength to density, their low density, the outstanding corrosion resistance [7, 8]. In the automotive field, one of the greatest applications of titanium-based materials is for components of the internal combustion engine area that equip the vehicle (pistons, valves, connecting rod, crank caps, bolts, etc.) $[9,10]$. Also, for modern jet turbine engines titanium alloys usually represent approximately $30 \%$ of the used materials, especially in the forward zone of the engine [11]. However, compared to other traditional materials, the major impediment represents the high cost of titanium [12]. Another disadvantage of titanium for applications in the automotive industry is its low tribological properties because of poor plastic shearing resistance and work hardening ability $[13,14]$.

Using inexpensive alloying elements (such as $\mathrm{Sn}, \mathrm{Mn}, \mathrm{Fe}, \mathrm{Cr}$, etc.) instead of expensive alloying metals ( $\mathrm{V}, \mathrm{Nb}, \mathrm{Mo}, \mathrm{Zr}$, etc.) to improve the strengthen alloys is one of the methods to reduce the cost of manufacturing titanium alloys [15].

Due to the properties they possess, by alloying Ti with small amounts of aluminium percentage a Ti-Al ( $\gamma$ Ti-Al) alloy is obtained with excellent mechanical properties and corrosion resistance at

Content from this work may be used under the terms of the Creative Commons Attribution 3.0 license. Any further distribution of this work must maintain attribution to the author(s) and the title of the work, journal citation and DOI. Published under license by Materials Research Forum LLC. 
temperatures above $700^{\circ} \mathrm{C}$, which allows the replacement for traditional Ni based superalloy for turbine engine components [16].

Due to the very good wear behaviour of tin, by adding small amounts of Sn percentage based Ti-alloys are obtained, such as Ti-5Al-2.5Sn which is a medium-strength all alpha alloy, used for gas turbine engine and other applications that request oxidation resistance, good weld fabric ability and intermediate strength at temperatures up to $4800{ }^{\circ} \mathrm{C}$ [17].

Manganese is a metal that has Fe-like properties, being a good substitute for it, and improves wear resistance giving plasticity and good alloy elasticity, so adding small percentages of Mn to a Ti-based alloy gives remarkable properties [18, 19]. According to Wang [20], a novel near- $\alpha$ titanium alloy Ti-6.0Al-4.5Cr-1.5Mn was designed and prepared by the water-cooled copper crucible and present better mechanical strength compared other Ti-alloys which has been presented, but worse elongation because of the presence of Cr2Ti phase which may cause alloy's poor plasticity.

Carbon has Van der Waals bonds and has good wear behaviour, so, according to [21] the incorporation of a small amount of $\mathrm{Al}$ and $\mathrm{C}$ into the TiAlVSiCN will improve the hardness, wear and erosion resistance, and, also, lower production cost. Also, due to similar properties of Zr with those of Ti, in the last years, Ti-Zr alloys with zirconium contents ranging from 10 to $40 \mathrm{wt} \%$ have been investigated by melting process and were reported characteristics as excellent corrosion resistance with obvious applications in the automotive industry [22].

Another way of reducing the cost price in making alloys based on $\mathrm{Ti}$ is the use of Powder Metallurgy (PM) techniques [23, 24]. Accordingly to [25] a Ti-6Al-2Sn-4Zr-2Mo alloy produced by arc melting and powder metallurgy processes presents excellent mechanical properties and high resistance, in sections exposed to high temperatures. Toyota uses sintered titanium alloys Ti-6Al$4 \mathrm{~V} / \mathrm{TiB}$ and $\mathrm{Ti}-\mathrm{Al}-\mathrm{Zr}-\mathrm{Sn}-\mathrm{Nb}-\mathrm{Mo}-\mathrm{Si} / \mathrm{TiB}$ in the intake and exhaust engine valves, respectively, are used from Toyota for own cars [26].

Among the PM method that appears to offer the greatest opportunity for real cost reductions it is considered that Two-Steps (TSS) and Multiple-steps (MSS) Sintering Techniques allow to obtain different compositions and microstructures of $\mathrm{Ti}$ products [27] for automotive components.

Conventional methods used for obtaining titanium alloys require special conditions of controlled atmosphere which result in a high cost of obtaining these alloys [28]. For this reason, in the last decade, many studies have focused for the producing of Ti-alloys by Powder Metallurgy using $\mathrm{TiH}_{2}$ powder [29-34]. According to [35] a Ti-6Al-2Sn-4Zr-2Mo alloy was obtained by Powder Metallurgy using titanium hydride powders. This alloy based on $\mathrm{TiH}_{2}$ powders proved an improvement of the mechanical properties and high corrosion resistance on high temperatures.

For this study, was proposed to obtain a titanium hydride alloy by adding small percentages of $\mathrm{Al}, \mathrm{Sn}, \mathrm{Mn}, \mathrm{Zr}$ and $\mathrm{C}$ in order to improve the mechanical and tribological properties of this alloy, and further processing to be achieved by compacting and sintering, using the TSS and MSS techniques.

\section{Experimental Procedures Materials}

For this research, titanium hydride $\left(\mathrm{TiH}_{2}\right)$ produced by Chemetall $\mathrm{GmbH}$, has been used as initial material. The following chemical elements are present in $\mathrm{TiH}_{2}$ composition: Titanium (min 95\%), Hydrogen (min. 3.8\%), Al (max.0.15\%), Si (max.015\%), Nitrogen (max.0.3\%), Fe, Ni, Cl, Mg, C, $\mathrm{Ni}$ (all the last component are under 0.1\%). In order to improve the mechanical and tribological characteristics in the initial powder were introduced by mixing for $60 \mathrm{~min}$ the following 
components: Mn powder, Sn powder, Alumix 321, 8\% powder, Zr powder, and graphite powder. The mixing and homogenization of the mixture was carried out in a ball mill Planetary Mono Mill PULVERISETTE 6 classic line from Fritsch with ball: powders ratio 1:1, $250 \mathrm{ml}$ grinding bowl, argon atmosphere, balls material stainless steel - 1.3541 ISO/EN/DIN codeX47Cr14, B50, rotational speed of main disk of $200 \mathrm{rpm}$. The weight ratio between the components is: $80 \% \mathrm{wt}$. $\mathrm{TiH}_{2}$, 8\%wt., Mn, 3\%wt. Sn, 2\%wt. Zr, 6\%wt. Alumix321, and 1\%wt. C. Particle size distributions, Fig. 1, was studied by dynamic laser scattering (DLS) using a 90Plus particle size analyser, Brookhaven Instruments Corporation, USA, equipped with $35 \mathrm{~mW}$ solid state laser, having $660 \mathrm{~nm}$ wavelength. The temperature was $25^{\circ} \mathrm{C}$ and the scattering angle was $90^{\circ}$. The dilution of the powders was made in water and the solution was subjected to ultrasonic treatment for 5 minutes to avoid flocculation of the particles.

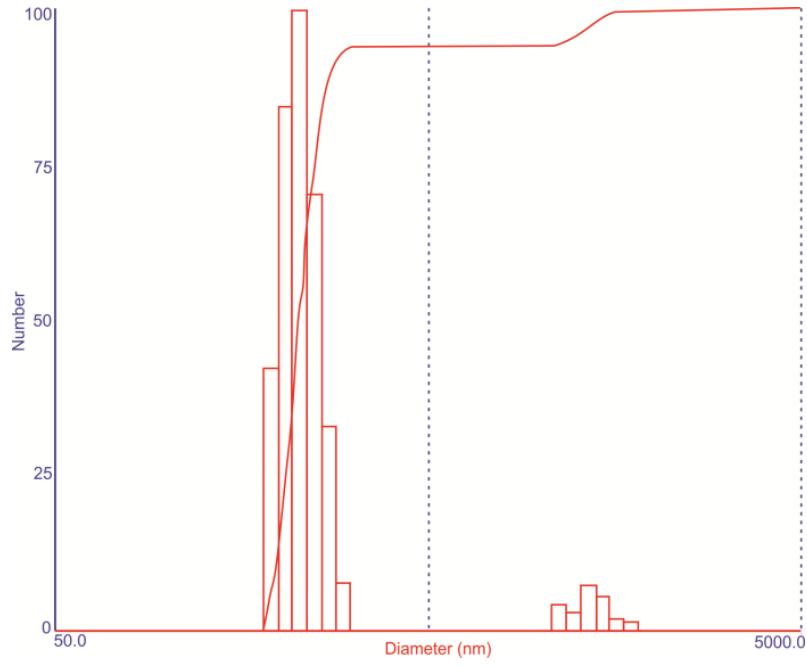

Fig. 1. Particle size distribution of the mixture.

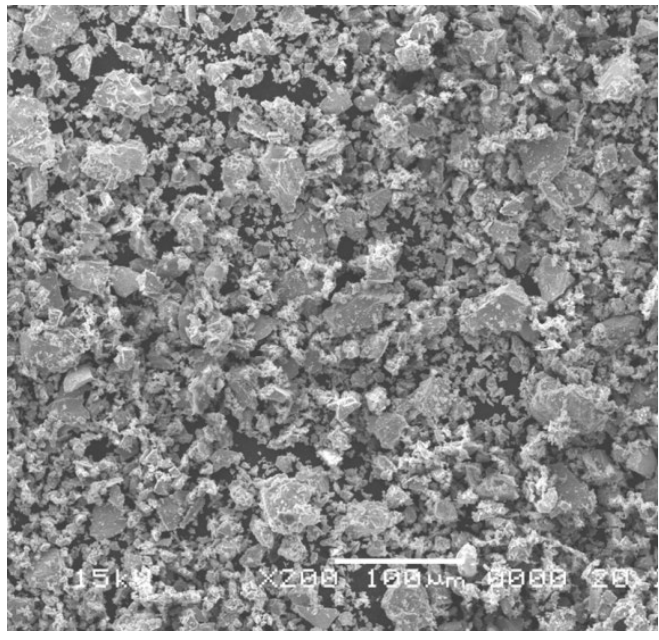

Fig. 2. SEM image of the mixture.

In Fig. 2 a SEM image of the mixture is shown. The mixture presents a bimodal particle size distribution, having particles with dimensions between $(188-294 \mathrm{~nm})$ respectively (1110-1730 $\mathrm{nm}$ ). The highest number of particles ( $28 \%$ from the total number) have the dimension equal to $225 \mathrm{~nm}$. The percent of the particles with higher size is lower than $1.5 \%$. The mean hydrodynamic diameter is $291 \mathrm{~nm}$. In Table 1 sub-micron dimensions and percentages of the powder particles accordingly with the grain-size distribution presented in Fig. 1 are shown.

\section{Methods and Techniques}

The homogenized mixture has been pressed by unilateral cold compaction at 600MPa compaction pressure, as cylindrical specimens with 12,05 mm diameter. An A009 electromechanicalcomputerized testing machine $100 \mathrm{kN}$ equipped with TCSoft2004Plus software was used for unilateral cold compaction. The green density of each part has been determined as has been presented in a previous study [27]. The next step was the sintering of the green compacts. They have used four different sintering regimes using Powder Metallurgy techniques as following:

- V1 regime, using classical sintering at $1050{ }^{\circ} \mathrm{C}$ for 90 min dwell time;

- Two-steps sintering (TSS) regime, V2, at $1050{ }^{\circ} \mathrm{C}$ with dwell time of $15 \mathrm{~min}$ and, then, at 1000 ${ }^{\circ} \mathrm{C}$ for $75 \mathrm{~min}$;

- TSS regime, V3, where the sintering was done at $1050{ }^{\circ} \mathrm{C}$ for $15 \mathrm{~min}$ and at $950{ }^{\circ} \mathrm{C}$, for $75 \mathrm{~min}$, Fig. 3; 
- Multiple-steps sintering (MSS), V4, in three steps at $1050{ }^{\circ} \mathrm{C}$ for 15 min dwell time, $1000{ }^{\circ} \mathrm{C}$ for 20 min dwell time and $900{ }^{\circ} \mathrm{C}$ for 55 min dwell time, Fig. 4.

Table 1. Grain-size distribution and percentages of the powder particles

\begin{tabular}{|c|c|}
\hline Dimension [nm] & Particle size distribution [\%] \\
\hline 189 & $11.8 \%$ \\
\hline 206 & $23.6 \%$ \\
\hline 225 & $28 \%$ \\
\hline 246 & $19.6 \%$ \\
\hline 269 & $9.2 \%$ \\
\hline 294 & $1.9 \%$ \\
\hline 1110 & $1.1 \%$ \\
\hline 1213 & $0.8 \%$ \\
\hline 1326 & $2 \%$ \\
\hline 1448 & $1.4 \%$ \\
\hline 1583 & $0.3 \%$ \\
\hline 1729 & $0.3 \%$ \\
\hline
\end{tabular}

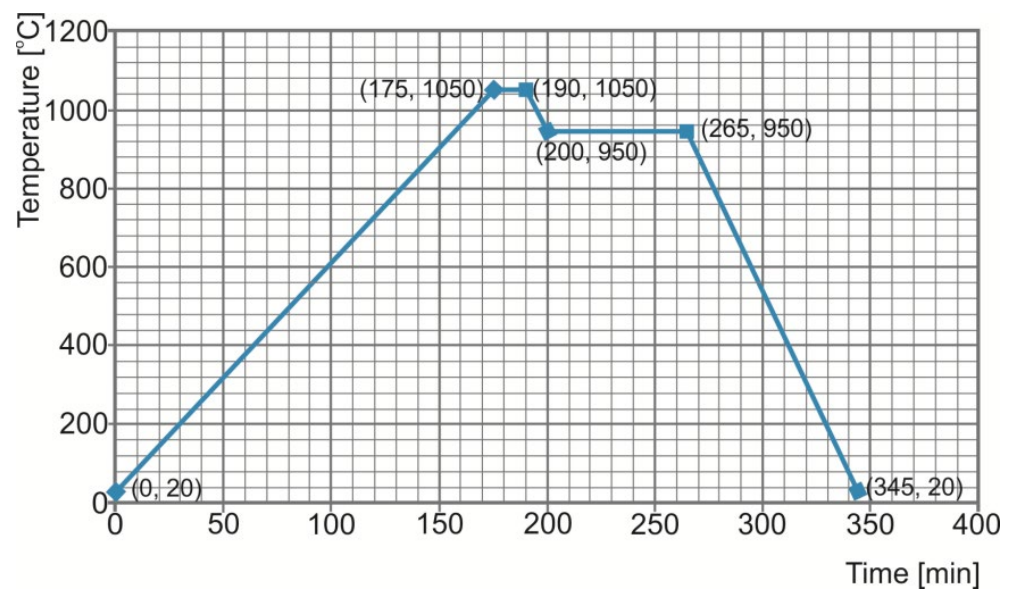

Fig. 3. TSS cycle for $1050^{\circ} \mathrm{C}$ and $950{ }^{\circ} \mathrm{C}$.

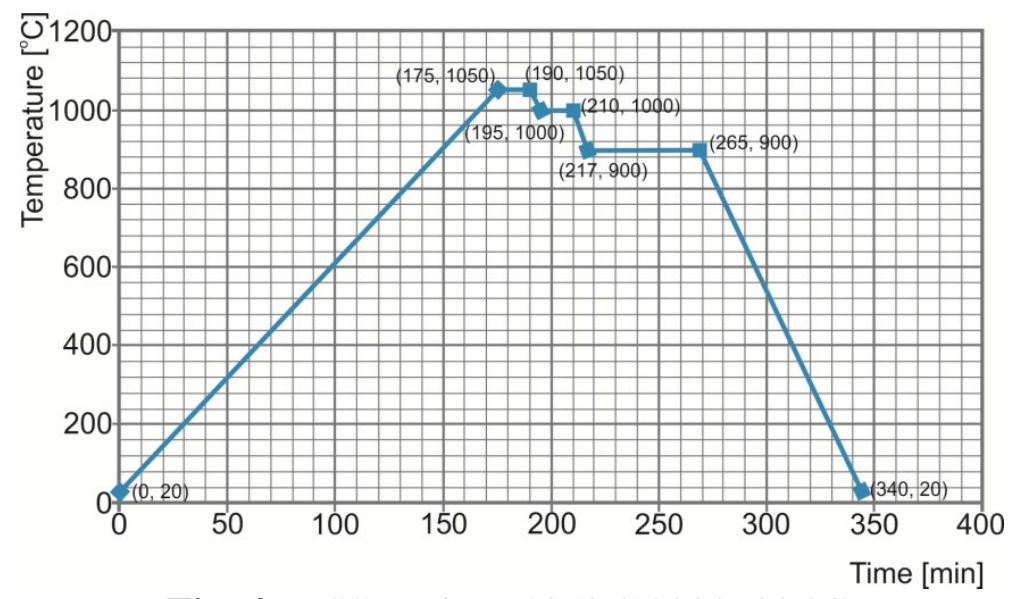

Fig. 4. MSS cycle at $1050 / 1000 / 900{ }^{\circ} \mathrm{C}$. 
The sintering treatments was done in Ar 99,9\% sintering atmosphere. The samples were heated into a Nabertherm L3/11/C6 furnace with $6{ }^{\circ} \mathrm{C} / \mathrm{min}$ heating rate for all four sintering cycles. For all 4 sintering cycles, the maximum temperature that was achieved was $1050{ }^{\circ} \mathrm{C}$ and the total cumulative dwell time was the same for all the specimens, 90 minutes, but, with different steps and sintering dwell times [36].

\section{Results and discussion}

The cylindrical sintered specimens were analysed by scanning electron microscopy (SEM) using a 5th generation Phenom desktop SEM platform. Superficial surface analysis has highlighted the specific porosity of particle parts and the roughness has values between 3.77-5.24 $\mu \mathrm{m}$ for $\mathrm{Ra}$ roughness parameter, as shown in Fig. 5.

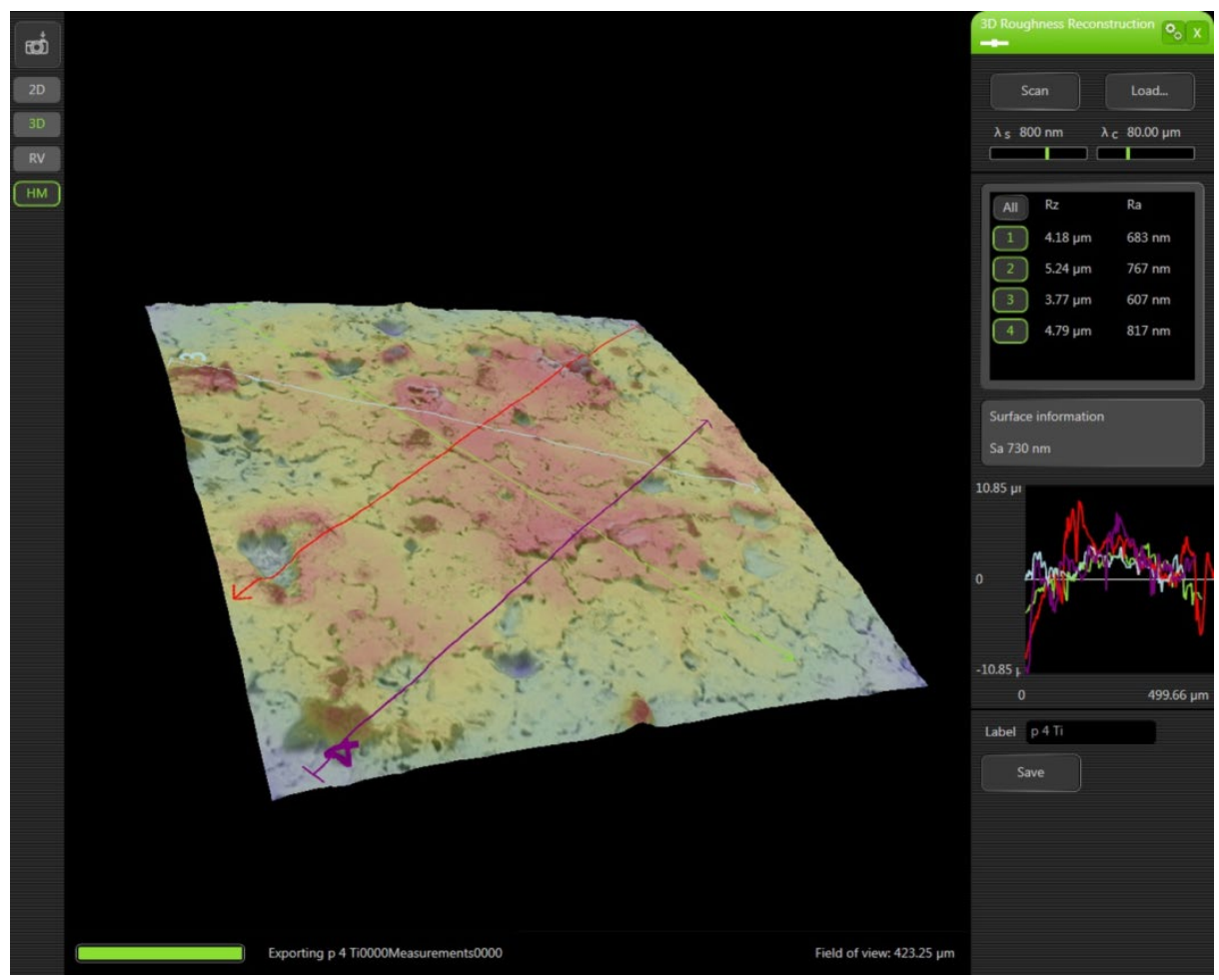

Fig. 5. 3D Surface roughness of sample for version V1 (sintering temperature $1050^{\circ} \mathrm{C} / 90 \mathrm{~min}$ ).

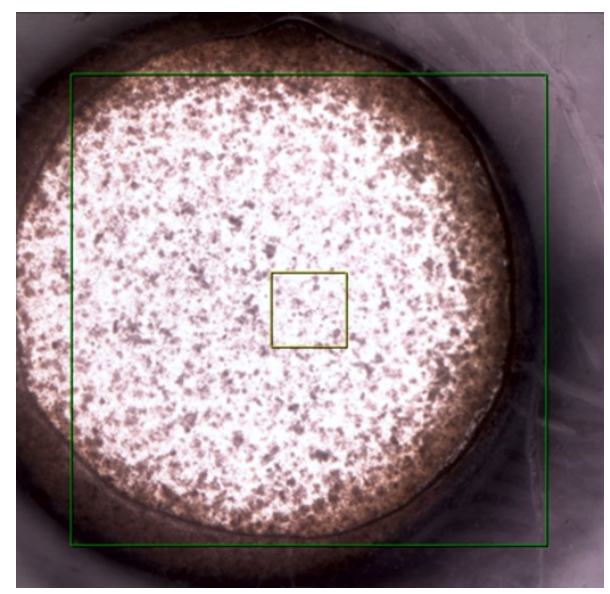

Fig. 6. Type of sintering sample for all the studied cases. 
The sample structures was physically examined with an integrated spectrometer for EDS analysis. This device has an optical magnification from 20x to 135x, SEM magnification from 80 up to $150.000 x$, resolution: < $10 \mathrm{~nm}$ and digital zoom: maximum 12x. Fig. 6 presents the type of sample which was analysed by SEM in this study.
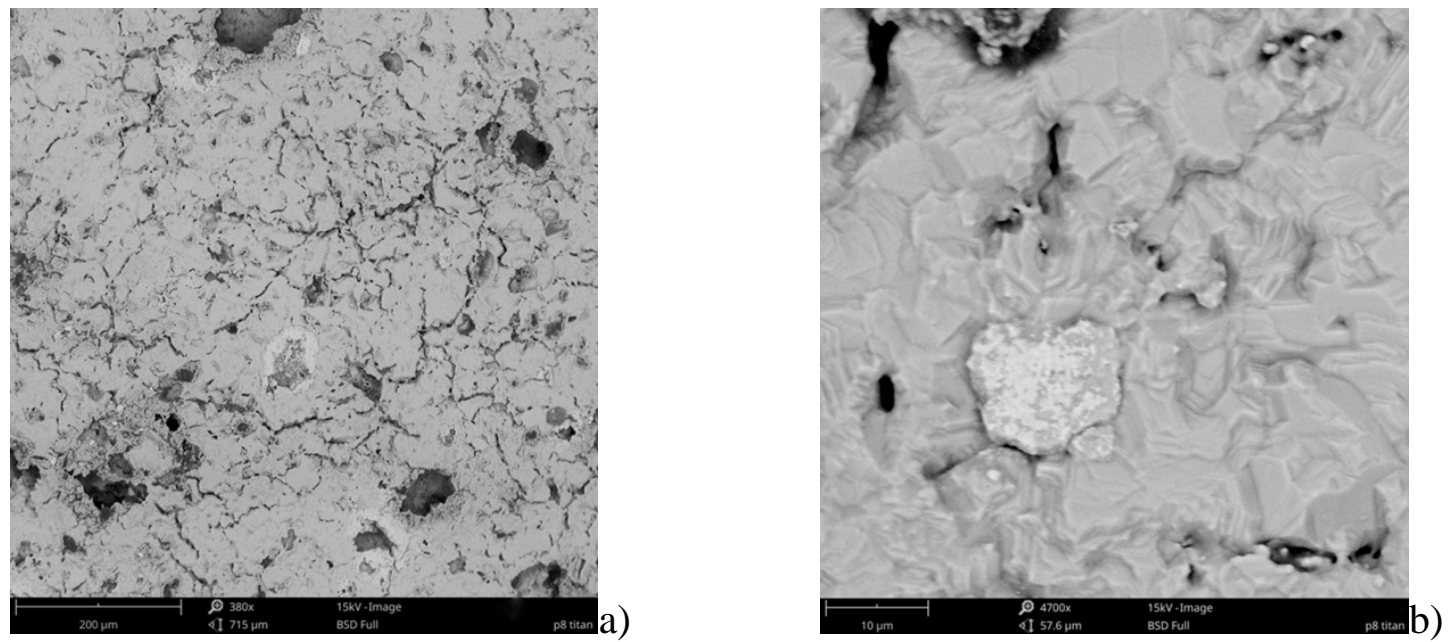

Fig. 7. Scanning electron microscopy (SEM) of the sample obtained after version V1 (sintering temperature $1050{ }^{\circ} \mathrm{C} / 90 \mathrm{~min}$ ): $\mathrm{a}-\mathrm{x} 200 \mu \mathrm{m} ; \mathrm{b}-\mathrm{x} 10 \mu \mathrm{m}$.

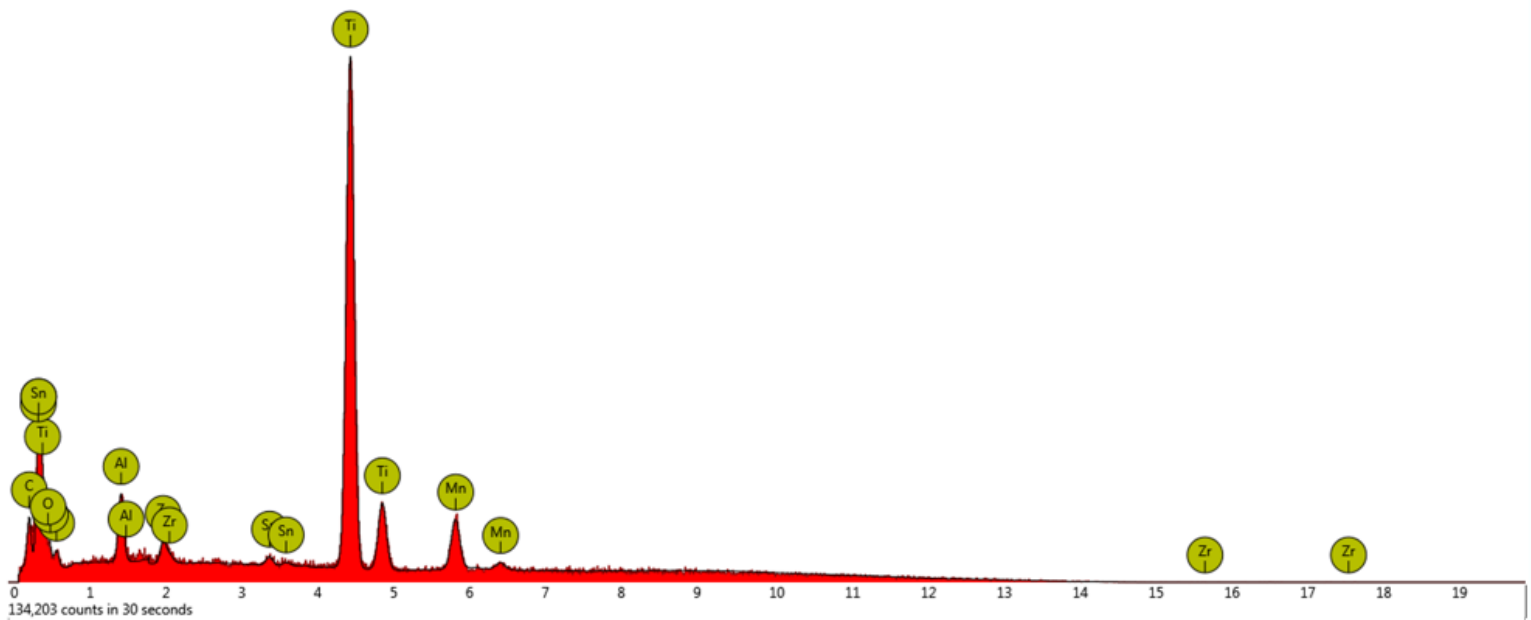

Fig. 8. Spectrometry elemental analysis of the sample obtained after version V1 (sintering temperature $\left.1050^{\circ} \mathrm{C} / 90 \mathrm{~min}\right)$.

Fig. 7, 9, 11 and 13 present SEM images for all four studied cases, with two orders of magnitude for each sample. Also, the spectrometry elemental analysis for all versions are presented in Figures 8, 10, 12, 14. The shown structures are in nonchemical etching metallographic state. At the sintering temperature used titanium forms solid solutions type $\beta$-Ti with all the alloying elements used, as shown in the equilibrium diagrams. The finishing structure is influenced by de sub-micron dimensions of the particles, like is presented in Fig. 1. The 
resulting structures are due of this phenomenon and highlight compact structures with some mass agglomerations of carbon, Fig. 15 spot 3 and 4.
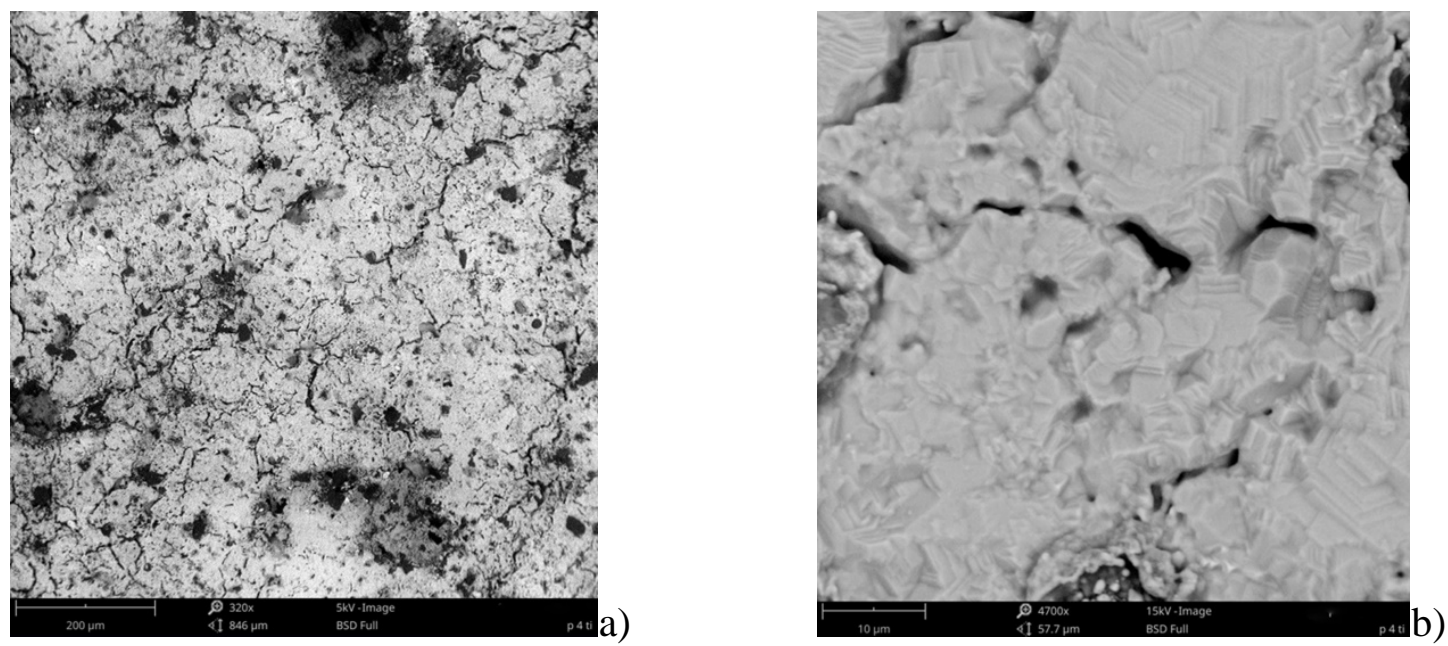

Fig. 9. Scanning electron microscopy (SEM) of the sample obtained after version V2 (sintering temperature $1050{ }^{\circ} \mathrm{C} / 15 \mathrm{~min}-1000{ }^{\circ} \mathrm{C} / 75 \mathrm{~min}$ ): $\mathrm{a}-\mathrm{x} 200 \mu \mathrm{m} ; \mathrm{b}-\mathrm{x} 10 \mu \mathrm{m}$.

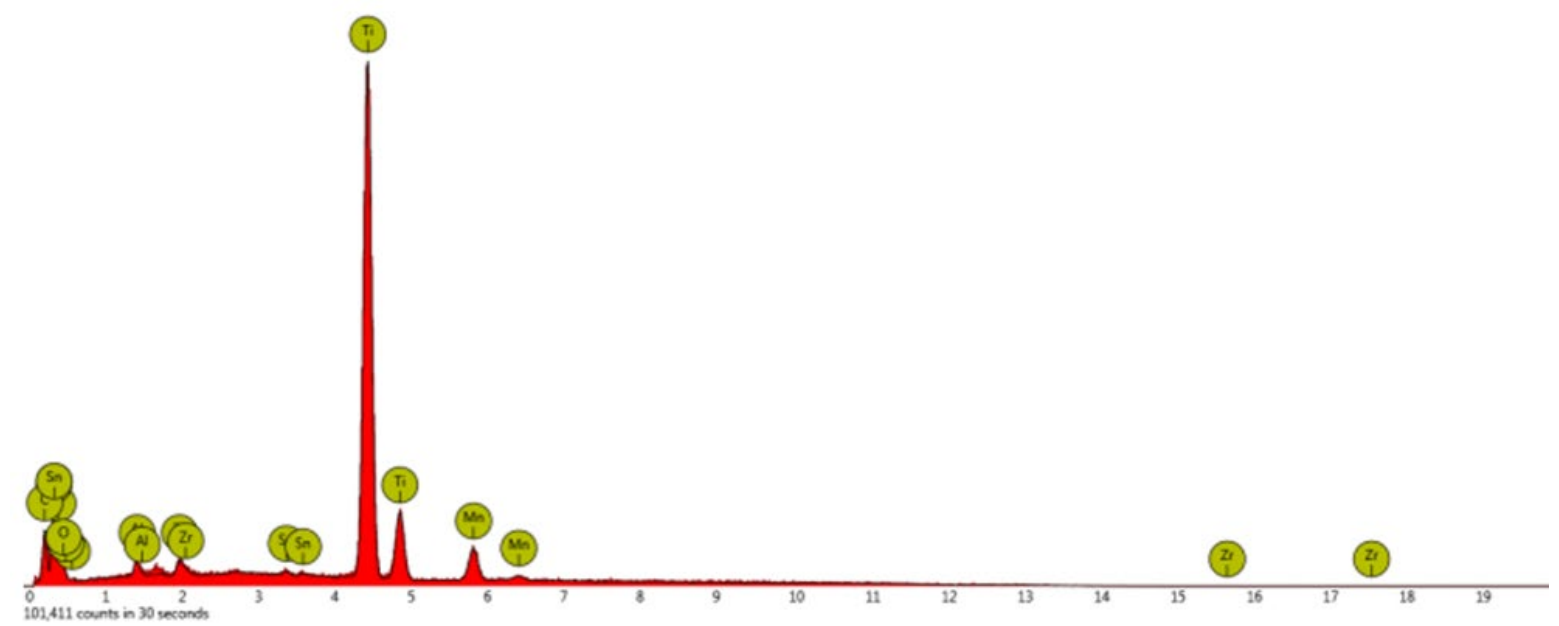

Fig. 10. Spectrometry elemental analysis of the sample obtained after version V2 (sintering temperature $1050^{\circ} \mathrm{C} / 15 \mathrm{~min}-1000^{\circ} \mathrm{C} / 75 \mathrm{~min}$ ). 

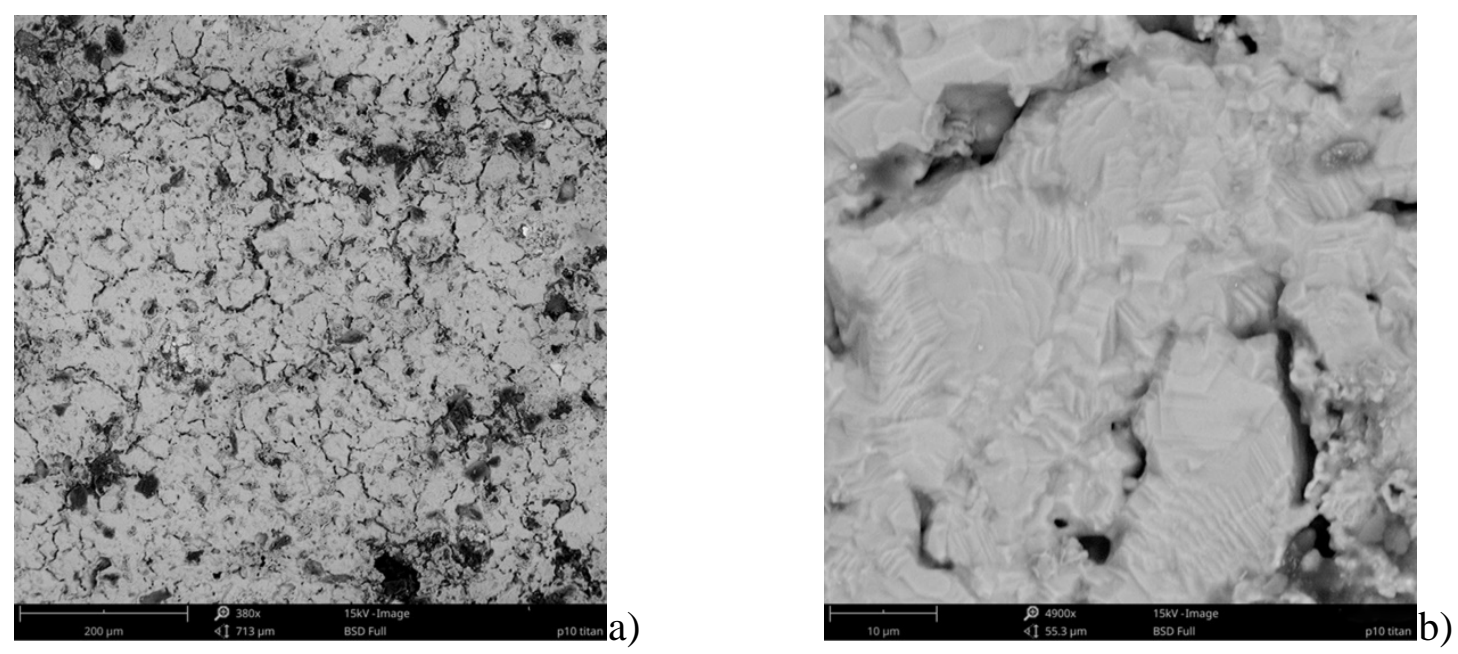

Fig. 11. Scanning electron microscopy (SEM) of the sample obtained after version V3 (sintering temperature $1050{ }^{\circ} \mathrm{C} / 15-950{ }^{\circ} \mathrm{C} / 75 \mathrm{~min}$ ): $\mathrm{a}-\mathrm{x} 200 \mu \mathrm{m} ; \mathrm{b}-\mathrm{x} 10 \mu \mathrm{m}$.

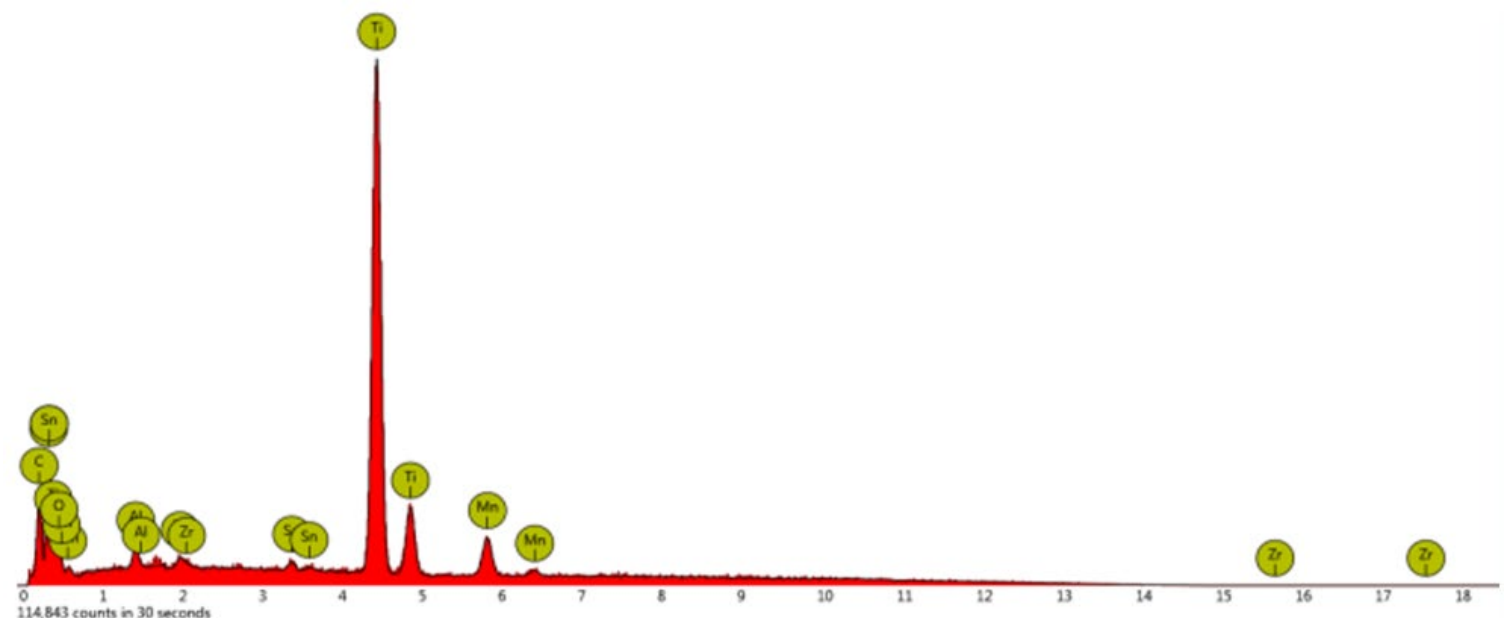

Fig. 12. Spectrometry elemental analysis of the sample obtained after V3 (Sintering temperature $\left.1050{ }^{\circ} \mathrm{C} / 15-950{ }^{\circ} \mathrm{C} / 75 \mathrm{~min}\right)$.
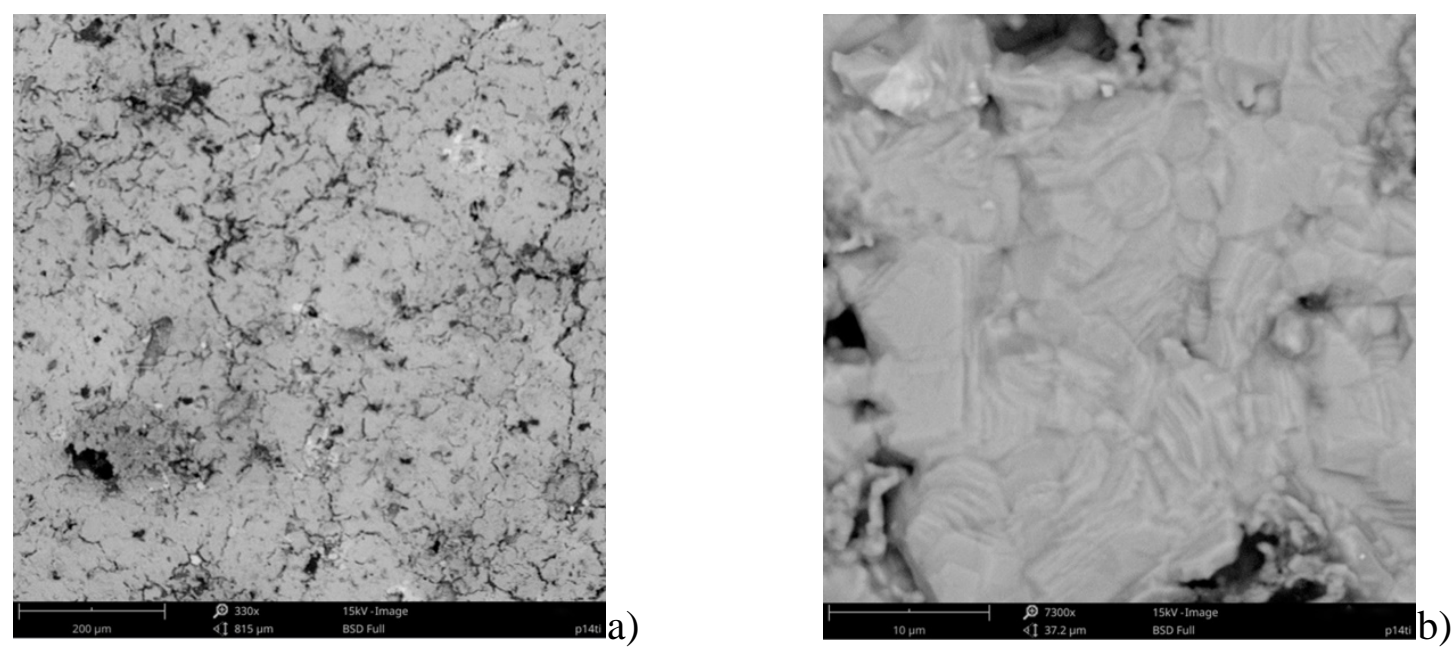

Fig. 13. Scanning electron microscopy (SEM) of the sample obtained after version V4 (sintering temperature $1050{ }^{\circ} \mathrm{C} / 15-1000{ }^{\circ} \mathrm{C} / 20 \mathrm{~min}-900{ }^{\circ} \mathrm{C} / 55 \mathrm{~min}$ ): $\mathrm{a}-\mathrm{x} 200 \mu \mathrm{m} ; \mathrm{b}-\mathrm{x} 10 \mu \mathrm{m}$. 


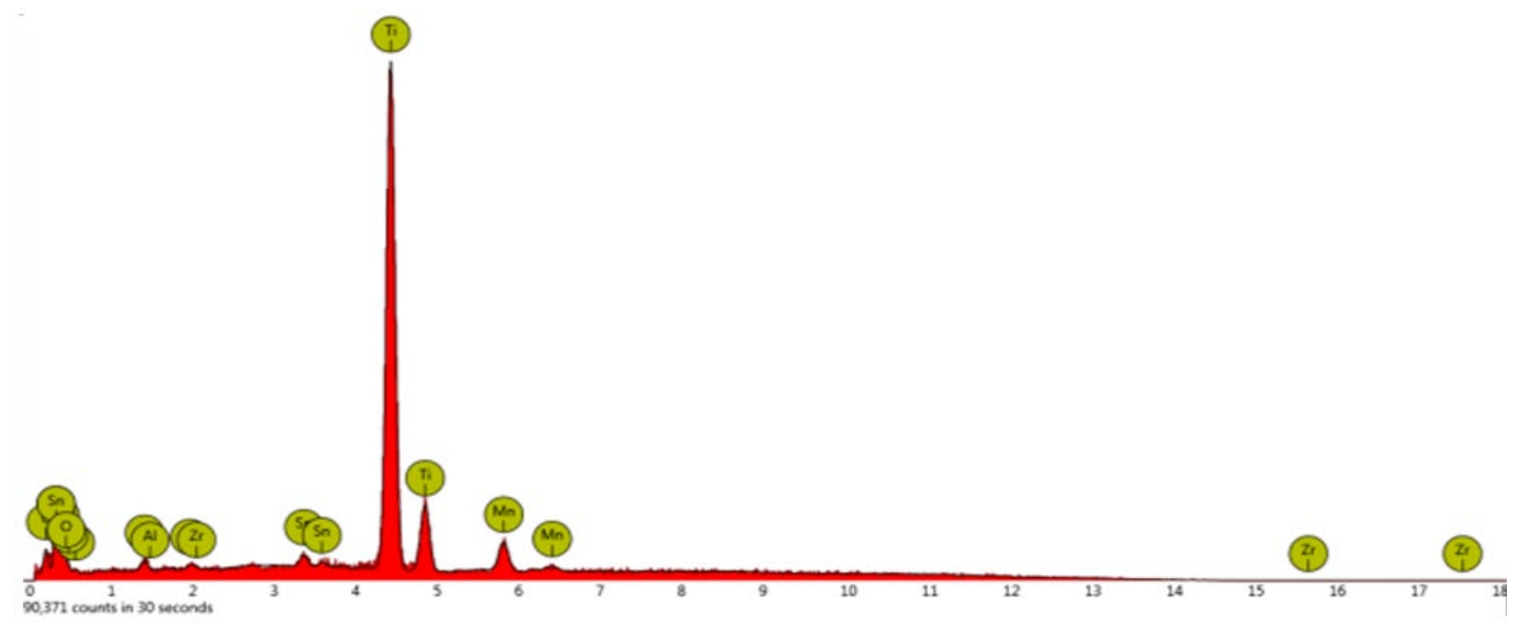

Fig. 14. Spectrometry elemental analysis for version V4 (sintering temperature $1050{ }^{\circ} \mathrm{C} / 15-1000$ $\left.{ }^{\circ} \mathrm{C} / 20 \mathrm{~min}-900{ }^{\circ} \mathrm{C} / 55 \mathrm{~min}\right): \mathrm{a}-\mathrm{x} 200 \mu \mathrm{m} ; \mathrm{b}-\mathrm{x} 10 \mu \mathrm{m}$.

SEM analysis reveal that the volume of surface pores is reduced during the sintering process and the space between the particles shrinks during the sintering process. Due to this phenomena, the contacted particle surfaces fuse together during sintering. Also, the spectral analysis used has identified the presence of all alloying elements, as well some traces of oxygen are visible. A further reduction process probably is needed [38].

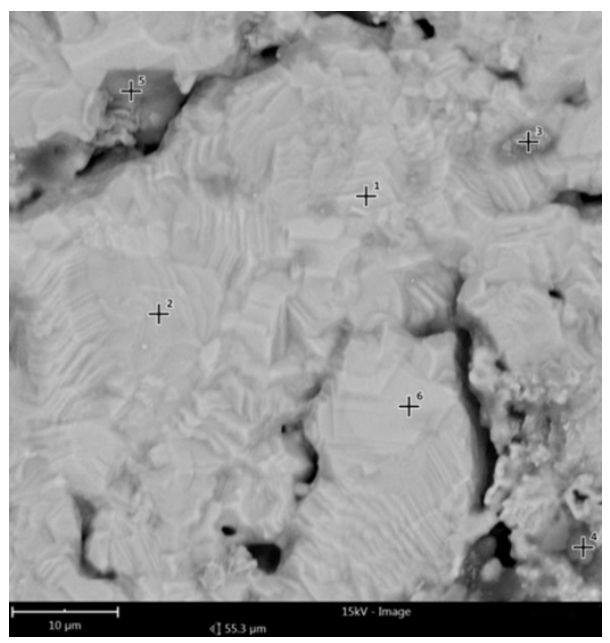

Fig. 15. SEM analysis with indication of spots investigated by spectral analysis.

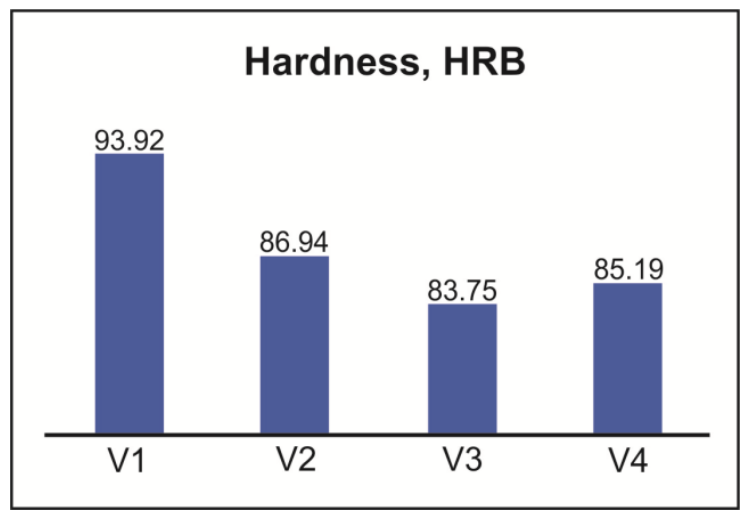

Fig. 16. HRB Hardness of the sintered samples.

The density and HV micro-hardness were also determined. It has been observed that the density of the sintered parts ranged between $3.59-3.65 \mathrm{~g} / \mathrm{cm}^{3}$ [36], reached over $90 \%$ of the theoretical density of the titanium hydride-based alloy, which means that it has been produced the densification process. This fact, according to [24,39] allows the use of Ti-based alloy in the manufacture of components in the automotive field. The hardness of the specimens was measured after sintering by the Vickers method and the results were equated in HRB units. The samples were metallographic prepared and were analysed with a Nikon Eclipse MA 100 microscope which 
is equipped with NIS ELEMENTS acquisition data software. The Vickers microhardness HV1 was determined using an NAMICON 400-DTS tester. The dwell time was 15 seconds. As shown in Fig. 16, the average values of microhardness exceed $80 \mathrm{HRB}$, which is comparable to the known hardness values of pure titanium and $6 \mathrm{Al}-4 \mathrm{~V}$ titan alloy very used in automotive and aerospace applications [37]. The maximum value is $93.92 \mathrm{HRB}$ in regime 1 (sintering $1050{ }^{\circ} \mathrm{C}$ with 90-minute hold), followed by $86.94,85.19$ and $83.75 \mathrm{HRB}$ for regime $2\left(1050^{\circ} \mathrm{C} / 15 \mathrm{~min}\right.$ $\left.1000^{\circ} \mathrm{C} / 75 \mathrm{~min}\right), \mathrm{V} 4\left(1050^{\circ} \mathrm{C} / 15 \mathrm{~min}-1000^{\circ} \mathrm{C} / 20 \mathrm{~min}-900^{\circ} \mathrm{C} / 55 \mathrm{~min}\right), \mathrm{V} 3\left(1050^{\circ} \mathrm{C} / 15 \mathrm{~min}-\right.$ $\left.950^{\circ} \mathrm{C} / 75 \mathrm{~min}\right)$. As with the behaviour of this sintering alloy, where the density increases were higher for the regime 4 than for the regime 3, the same type of behaviour is found in terms of material hardness. The explanation lies in the fact that the intermediate dwell at $1000{ }^{\circ} \mathrm{C}$ in the regime 4 helps to increase the hardness even if the final $900{ }^{\circ} \mathrm{C}$ dwell is lower, in this case the 950 ${ }^{\circ} \mathrm{C}$ range used in the regime 3 .

\section{Summary}

The time for mixing powder in mechanical mill (1 hour) allows for the mixture to have submicron mean hydrodynamic diameter $(291 \mathrm{~nm})$. The 600MPa mechanical pressure is good enough to have a compact samples with a good green density. Sintering temperature of $1050{ }^{\circ} \mathrm{C}$ combined with different smaller dwells allows the samples to improve their density. The structures of sintered titanium alloy are influenced by the sub-micron dimensions of powder and the time of mechanical alloying time too. The HRB hardness has a maximum value equal with $94 \mathrm{HRB}$ then the sintering temperature is $1050{ }^{\circ} \mathrm{C}$ with 90 minutes hold. Alloying elements such as Sn and graphite improve the wear resistance of titanium based alloys that are destined for the automotive industry [26]. Also, by using $\mathrm{TiH}_{2}$ as initial material the densification process seems to be achieved at $1050{ }^{\circ} \mathrm{C}$, the density and hardness of the sintered alloy are comparable to those presented in [37, 39] for materials used in the field of automotive components.

\section{References}

[1] M. Qian, Cold compaction and sintering of titanium and its alloys for near-net shape or preform fabrication, Int. J. Powder Metall. 46 (2010) 29-44.

[2] M.J. Donachie, Titanium: a technical guide. $2^{\text {nd }}$ ed. Materials Park (OH): ASM International; 2000.

[3] G. Lütjering, J.C. Williams. Titanium. Heidelberg, Germany: Springer; 2007.

[4] M.N. Gungor, M.N. Imam M.A. Froes F.H, Innovations in Titanium Technology, Warendale: Wiley's Publishing; 2007.

[5] R. Boyer, G. Welsch, E.W. Collings, Materials Properties Handbook: Titanium Alloys, ASM International, 1994.

[6] I.M. Robertson, G.B. Schaffer, Review of densification of titanium based powder systems in press and sinter processing, Powder Metall., 53 (2010) 146-162. https://doi.org/10.1179/174329009X434293

[7] H. Fujii, K. Takahashi, Y. Yamashita, Application of Titanium and Its Alloys for Automobile Parts, Nippon Steel Tech. Report., 38 (2003) 70-75.

[8] A. Mayyas, A. Qattawi, M. Omar, D. Shan, Design for sustainability in automotive industry: A comprehensive review, Renew. Sust. Energ. Rev., 16 (2012) 1845-1862. https://doi.org/10.1016/j.rser.2012.01.012

[9] O. Schauerte, Titanium in Automotive Production, Adv. Eng. Mat., 5 (2003) 411-418. https://doi.org/10.1002/adem.200310094 
[10] F.H. Froes, H. Friedrich, J. Kiese, D. Bergoint, Titanium in the Family Automobile: the Cost Challenge, Trans Tech Publications: Zurich; Switzerland; 2010.

[11] G.R. Watkins, Development of a High Temperature Titanium Alloy for Gas Turbine Applications, PhD. Thesis, The University of Sheffield, March 2015.

[12] R.B. Boyer, Attributes, Characteristics, and Applications of Titanium and Its Alloys, JOM, 62 (2010) 35-43. https://doi.org/10.1007/s11837-010-0071-1

[13] A. Ohidul, M. Haseeb, ASMA. Response of Ti-6Al-4V and Ti-24Al-11Nb alloys to dry sliding wear against hardened steel, Tribol. Int. $35 \quad$ (2002) 357-362. https://doi.org/10.1016/S0301-679X(02)00015-4

[14] K.M. Chen, Y. Zhou, X. X. Li, Q. Y. Zhang, L. Wang, S.Q. Wang, Investigation on wear characteristics of a titanium alloy/steel tribo-pair, Adv Mater Res-Switz. 65 (2015) 65-73. https://doi.org/10.1016/j.matdes.2014.09.016

[15] Z. Kailiang, N. Gui, T. Jiang, M. Zhu, X. Lu, J. Zhang, C. Li, The Development of the Low-Cost Titanium Alloy Containing $\mathrm{Cr}$ and Mn Alloying Elements, Metall. Mater. Trans. A 45A (2014) 1761-1766.

[16] V. Henriques, J. de Oliveira, E. Diniz, A. Dutra. et al., Development of Techniques for Gamma Ti-Al Production, 22 ${ }^{\text {nd }}$ SAE Brasil International Congress and Display, 2013, https://doi.org/10.4271/2013-36-0392.

[17] R. Boyer, G. Welsch, E.W. Collings, Materials Properties Handbook: Titanium Alloys, ASM International; USA; 2007.

[18] D. Lehmhus, M. Busse, A. Herrman, K. Kayvantash, Structural Materials and Processes in Transportation, Wiley-VCh Verlag GmbH \& Co, Weinheim, Germany, 2013.

[19] M.J. Gázquez, J.P. Bolívar, R. Garcia-Tenorio, F. Vaca, A Review of the Production Cycle of Titanium Dioxide Pigment, Mater. Sci. Appl., 5 (2014) 441-458. https://doi.org/10.4236/msa.2014.57048

[20] H. Wang, S. Wang, P. Gao, C.H. Li, Microstructure and mechanical properties of a novel near- $\alpha$ titanium alloy Ti6.0A14.5Cr1.5Mn, Adv Mater Res-Switz, 67 (2016) 170-174. https://doi.org/10.1016/j.msea.2016.06.083

[21] J. Lin, R. Wei, F. Ge, M. Lei, TiSiCN and TiAlVSiCN nanocomposite coatings deposited from Ti and Ti-6Al-4V targets, Surf Coat Techn. 2017.

[22] T. Luz, V. Henriques, J. de Oliveira, E. Diniz, Production of Ti-Zr Alloy by Powder Metallurgy, SAE Technical Paper 2013.

[23] F.H.S. Froes, Powder metallurgy of titanium alloys. In: Chang I, Zhao Y, editors. Advances in powder metallurgy. Cambridge: Woodhead Publishing; 2013. p. 202-240. https://doi.org/10.1533/9780857098900.2.202

[24] C.A. Lavender, V.S. Moxson, V.A. Duz, Cost-Effective Production of Powder Metallurgy Titanium Auto Components for High-Volume Commercial Applications, 2010, http://www.pnl.gov/main/publications/external/technical_reports/PNNL-19932.pdf.

[25] R. Pereira, V. Henriques, J. de Oliveira, E. Diniz, Development of Production Techniques for Aerospace Titanium Alloys, SAE Technical Paper 2013, https://doi.org/10.4271/2013-360370 .

[26] C. Veiga, J.P. Davim, A.J.R. Loureiro, Properties and applications of titanium alloys: A brief review, Rev.Adv.Mater.Sci. 32 (2012) 14-34. 
[27] C.I. Pascu, S. Gheorghe, C. Nicolicescu, Aspects about Sintering Behaviour of a Titanium Hydride Powder based Alloy used for Automotive Components, Applied Mech. Mater. 823 (2016) 467-472.

[28] E. do Nascimento Filho, V. Henriques, J. de Oliveira, E. Diniz, Microstructural Study of Ti-6Al-4V Produced with $\mathrm{TiH}_{2}$ Powder, SAE Technical Paper 2012, https://doi.org/10.4271/201236-0197.

[29] O. Ivasishin, V. Moxson, Low-cost titanium hydride powder metallurgy, in: Ma Qian and F. H. Froes (Est), Titanium hydride powder metallurgy, Science, Technology and Applications, Elsevier Inc., Library of the Congress, New York, 2015; 117-148. https://doi.org/10.1016/B978-012-800054-0.00008-3

[30] I.M. Robertson, G.B. Schaffer, Comparison of sintering of titanium and titanium hydride powders, Powder Metall. 53 (2010) 12-19. https://doi.org/10.1179/003258909X12450768327063

[31] V. Henriques, J. de Oliveira, E. Diniz, T. Lemos, Densification of titanium alloys obtained by powder metallurgy, SAE Technical Paper 2010, https://doi.org/10.4271/2010-36-0235.

[32] H.T. Wang, M. Lefler, Z.Z. Fang, T. Lei, S. M. Fang, J.M. Zhang, Q. Zhao, Titanium and Titanium Alloy via Sintering of $\mathrm{TiH}_{2}$, Key Eng. Mat. 436 (2010) 157-163. https://doi.org/10.4028/www.scientific.net/KEM.436.157

[33] Z.Z. Fang, P. Sun, H. Wang, Hydrogen Sintering of Titanium to Produce High Density Fine Grain Titanium Alloys, Adv. Eng. Mat. 14 (2012) 383-387. https://doi.org/10.1002/adem.201100269

[34] D.W. Lee, H.S. Lee, J.H. Park, S.M. Shin, J.P. Wang, Sintering of Titanium Hydride Powder Compaction, 2nd International Materials, Industrial, and Manufacturing Engineering Conference, MIMEC2015, Procedia Manufacturing 2 (2015) 550 - 557.

[35] H. Sargentini, T. Lemos, A. Henriques, J. Faria, Development of titanium alloys production for high temperatures applications, SAE Technical Paper 2010, https://doi.org/10.4271/2010-36-0170.

[36] C.I. Pascu, S. Gheorghe, D. Tarata, C. Nicolicescu, C. Miritoiu, Study about the Influence of Two-Steps Sintering (TTS) Route for an Alloy based on Titanium, Applied Mech. Mater. 880 (2018) 256 - 261.

[37] G. Ozkan, V. Gülsoy, V. Günay, T. Baykara, R.M. German, Injection Molding of Mechanical Alloyed Ti $\neg \mathrm{Fe} \neg \mathrm{Zr}$ Powder, Mater. Transactions, 53 (2012) 1100-1105. https://doi.org/10.2320/matertrans.M2012031

[38]Y. Xia, Z.Z. Fang, T. Zhang, Y. Zhang, P. Sun, Z. Huang, Deoxigenation of titanium hydride with calcium hydride, Proceedings of the 13th World Conference on Titanium, San Diego, 2015; 867-875.

[39] S.J. Park, A. Arockiasamy, H. El Kadiri, W. Joost, Production of Heavy Vehicle Components from Low-Cost Titanium Powder, Contract No.: DE-FC-26-06NT42755, Mississippi State University, 2014, http://energy.gov/sites/prod/files/2014/04/f14/4_automotive_metalstitanium.pdf. 